\title{
Saving time
}

\author{
Time Restored: The Harrison Timekeepers \\ andR. T. Gould, the Man Who Knew \\ (Almost) Everything \\ by Jonathan Betts \\ Oxford University Press: 2006.480 pp. \\ $£ 35, \$ 69.50$
}

\section{Lisa Jardine}

In her best-selling popular science book Longitude, Dava Sobel told the tale of horologist John Harrison's eighteenth-century quest to design and build a precision timekeeper accurate enough to determine longitude at sea. Towards the end of the book, she introduces us to another 'lone genius' with a lifelong fascination with clocks, Lieutenant Commander Rupert T. Gould. It was Gould who, in the early twentieth century, found Harrison's chronometers neglected and largely forgotten in a cupboard at Greenwich Royal Observatory, where they had lain, "dirty, defective and corroded"', since the $1760 \mathrm{~s}$. Gould devoted much of the rest of his life to restoring them to their former glory.

Without Gould's efforts, we would not today have the pleasure of seeing Harrison's timekeepers, intact and in full working order, in their own gallery in the old observatory at Greenwich. Over a period of 13 years, Gould - who had no horological training - painstakingly dismantled the timepieces, cleaned every working part, arranged for the manufacture by specialist horologists of replacement and missing pieces, and rebuilt them, meticulously documenting every step in a series of illustrated notebooks.

Jonathan Betts' compelling, informationpacked new book, Time Restored, at last gives us a richly detailed account of Gould's life. It is a life every bit as colourful as Harrison's, and equally dogged by heartache and setback. Academically bright, although suffering from a debilitating lack of self-confidence, Gould seemed destined for a successful career in the Royal Navy. But on the eve of the First World War he suffered the first of a series of nervous breakdowns that were to blighthis life. His mental health collapsed again at the outbreak of the Second World War. His periods of clinical depression were brought on by fear of three things, he said: lightning, revolution and hell. In all, he experienced four major breakdowns, during which he suffered severe memory loss and was unable to speak for long periods. Recovery each time was slow. Working with his beloved clocks was what restored him and gave him a sense of purpose.

Perhaps as a result of his mood swings, Gould's private life was a disaster. As restoring the Harrison clocks became an obsession, he neglected his children, drank heavily at home, and saw his marriage to Muriel Estall disintegrate. She left the family home, taking their

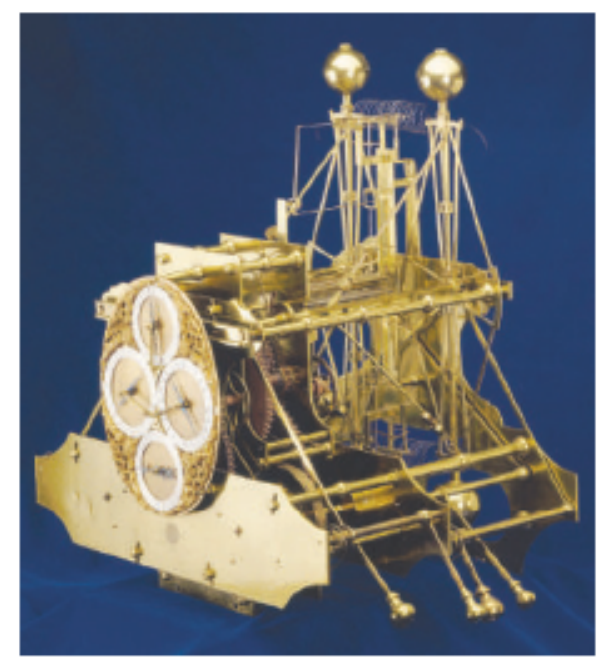

John Harrison's eighteenth-century timekeepers have been beautifully restored by Rupert T. Gould.

daughter Jocelyn with her. In the lawsuit that followed, the details of the couple's private life (she accused him of violence, drunken fits and unreasonable sexual demands) caused a scandal. Gould was ostracized by polite society and his job prospects were permanently damaged.

Gould's exceptional talents were not limited to clock restoration. He was a talented artist, producing both exquisite line drawings and bizarre imaginative art in the manner of Aubrey Beardsley. He wrote with flair and eloquence, captivating readers with a series of eccentric books on a range of curious topics, and gained a considerable reputation as a broadcaster, furst as a regular contributor to the BBC's children's hour, and then as a panellist on the intellectual radio roundtable, The Brains Trust.
Betts has produced a finely crafted biography, full of lovingly observed insight into Gould's character, including his many personal failings. But the book is much more than a biography. In the introduction, Betts tells us how he has loved clocks since childhood, and we learn that he is now in charge of preserving the Harrison timekeepers for posterity. Time Restored, then, is a loving restoration of a reputation, to set alongside the clocks to which both Gould and Betts have devoted so much care and attention.

Chapter 4 is a concise retelling of the whole longitude story, including a readily comprehensible account of precisely what the problem of longitude entails, and the technical details of the timekeepers that Harrison built to solve it. Here, in one book, readers can find an authoritative account of Harrison's quest, and details of the workings of the Harrison clocks, alongside the painstaking reconstruction of the complicated life of one of the key protagonists in the history of the timekeepers.

In Longitude, Sobel wrote that the restored Harrison timepieces at the Greenwich old observatory "constitute John Harrison's enduring memorial, just as St Paul's Cathedral serves as monument to Christopher Wren". Betts shows us with extraordinary elegance that in the case of the Harrison docks, the memorial is a double one: to Harrison and to Gould, the complicated, depressive, brilliant, failed navigation officer without whose obsessive attentions and unstinting labours the clocks would almost certainly have been lost for ever Lisa Jardine is director of the AHRC Centre for Editing Lives and Letters at Queen Mary, University of London, London E1 4NS, UK.

\section{6 wrapped up}

\section{Mary Purton}

It has been a strange year for science books. Some authors have presented new ideas about science - there has been a tussle over string theory, for example, and in Moral Minds Marc Hauser has suggested that morality is as innate as language (see Nature 443, 909-910; 2006). But perhaps the dominant theme running through many of the popular science books published this year has been, surprisingly, religion.

The continuing debate about the teaching of creationism in schools has no doubt fuelled this preoccupation. Many scientists, particularly those in the United States, have been moved to take a stand against proponents of creationism and intelligent design. Intelligent Thought, edited by John Brockman, is a collection of essays from the likes of Jerry Coyne and
Tim White who provide elegantly expressed scientific arguments to counter the claims of intelligent design. This book should appeal to "those who already see evolutionary biology as a science", according to John Tyler Bonner (see Nature 442, 355-356; 2006). Michael Shermer's Why Darwin Matters is perhaps more accessible for the public, but neither book is likely to sway creationists from their belief.

Many of the scientists who made it to the top of the bestseller lists focused specifically on religion. Daniel Dennett's book Breaking the Spell provides essentially a natural history of religion but skirts around the cultural reasons why religion has developed and become such a dominant force in politics today, in the view of reviewer Michael Ruse (see Nature 439, 535; 2006). In Six Impossible Things Before Breakfast, Lewis Wolpert treads similar ground but 
provides a more succinct summary of the evolution of the 'need to believe' (see Nature 442, $137 ; 2006$ ).

Francis Collins' The Language of God, an account of how his Christian faith is compatible with his work as a scientist, has sought to engage both sides in a less confrontational dialogue (see Nature 442, 110 and 114-115; 2006) - as has Owen Gingerich in God's Universe. But Richard Dawkins isn't interested in reconciling science and religion. In The God Delusion, which has topped the bestseller lists in both the United States and Britain this autumn, Dawkins argues with the fervour of a preacher that religion has no place in the modern world, and that atheism is the 'true path' (see Nature 443, 914-915; 2006).

Dawkins' domination of the genre of popular science books was celebrated earlier in the year with the publication by Oxford University Press of a thirtieth-anniversary edition of his book The Selfish Gene, and Richard Dawkins: How A Scientist Changed the Way We Think, a collection of comments and testimonials edited by Alan Grafen and Mark Ridley (see Nature 441, 151-152; 2006).

Physicists have also been questioning our place in the Universe. Cosmologist Alex Vilenkin's Many Worlds in One takes a look at the multiverse theory - the idea that many different universes exist and explanations for how we came to be in this one (see Nature 443, 145-146; 2006). Paul Davies' The Goldilocks Enigma gives the topic a more popular treatment (see Nature 444, 423-424; 2006). Playwright Michael Frayn also considers our relationship with the Universe, and much more, in his book The Human Touch, which will be reviewed in Nature next week.

After a spate of books on string theory in 2005, the hottest hope for a "theory of everything' came in for criticism this year, with the appearance of Lee Smolin's The Trouble with Physics and Peter Woit's Not Even Wrong (see Nature 443, 482, 491 and 507-508;2006).

Jane Goodall was the subject of one of the year's notable biographies, Jane Goodall by Dale Peterson (see Nature 443, 915; 2006). Philip Ball delved into history for The Devil's Doctor, his biography of Paracelsus (see Nature 441, 152-153; 2006). Broken Genius by Joel
Shurkin is the first full biography of William Shockley (see Nature 442, 631-632; 2006). And Francis Crick was the focus of a short biography by Matt Ridley (Francis Crick; see Nature $443,917-918$; 2006) - a fuller treatment by Robert Olby is expected next year. This year's Pulitzer Prize for biography, meanwhile, went to Kai Bird and Martin Sherwin for American Prometheus, their portrait of Robert Oppenheimer.

While many scientists have been preoccupied with religion, some novelists have turned to science for inspiration. Allegra Goodwin's Intuition proved to be an exciting page-turner, examining the psychological motives for scientific fraud in a cancer-biology lab (see Nature 440, 996-997; 2006). Die Vermessung der Welt by Daniel Kehlmann, a fictionalized account of scientists Alexander von Humboldt and Carl Friedrich Gauss, was a bestseller in Germany last year. AnEnglish translation by Carol Brown Janeway, Measuring the World, is now available and will be reviewed in Nature next month. Mary Purtonis Nature's book review editor.

\section{CHRISTMAS READING}

A selection of books on the lighter side of science for the holiday period.

\section{Why Don't Penguins' Feet Freeze?}

edited by Mick O'Hare (Profile, E7.99).

The book version of New Scientist's 'Last Word' column continues to top the bestseller lists in the run-up to Christmas with more than 180,000 copies sold in Britain sofar.

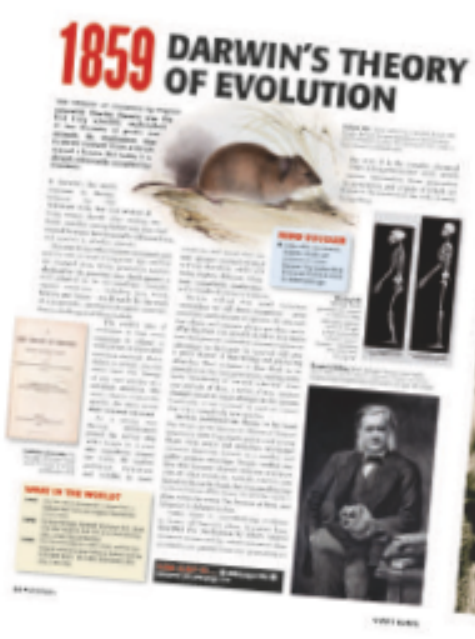

\section{Giant Leaps \\ by John Perry \& Jack Challoner (Boxtree, E12.99) \\ This is an amusingguide to the key discoveries, inventions and events in science, technology and medicine from UK newspaper The Sun and London's Science Museum, told in 'sensational' tabloid style (see picture).}

\section{Fly}

by Steven Connor (Reaktion Books, E12.95, \$19.95) Perhaps the perfect

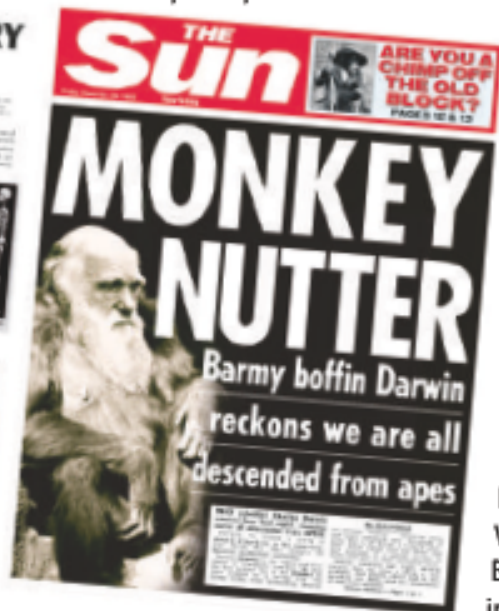

presentfor a Drosophila geneticist, this book is an exploration of flies through myth, literature, art and biology.

\section{How to Cut a Cake}

by lan Stewart (Oxford

University Press, £9.99, \$14.95)

Various mathematical

conundrums are featured, such as why phone cords get tangled, which way of tying shoelaces uses the shortest amount of lace, and how to play never-ending chess.

\section{Moths That Drink Elephants' Tears by Matt Walker (Portrait Books, E9.99) Why Pandas Do Handstands by Augustus Brown (Bantam Press, £9.99) These two are collections of facts aboutcurious animal behaviour. So if you want to know which cats purr and which don't, or why female brown trout fake orgasms, Walker's book is the one. Brown offers similar fare, including winking cuttlefish}

and tobogganing otters. Both have a bibliography butno index.

Bang! by Brian May, Patrick Moore \& Chris Lintott (Carlton, £20) Queen guitarist and astrophysicistMay joins the presenters of The Sky At Night for this lavishly illustrated "complete history of the Universe".

Ken Libbrecht's Field Guide to Snowflakes by Ken Libbrecht (Voyageur Press, \$12.95, £7)

Explore the icy world of snowflakes, from stellar dendrites to sectored plates, with this wonder of microphotography.

For more serious reading Oxford University Press has themed box sets from its Very Short Introductions series. The Brain Box ( $€ 25)$ has books on evolution (by Brian and Deborah Charlesworth), consciousness (Susan Blackmore), intelligence (lan Deary), cosmology (Peter Coles) and quantum theory (John Polkinghorne). 